\title{
Exploring Contemporary Security Issues Near Sarawak-Kalimantan Border
}

\author{
NUURRIANTI JALLI \\ ISMAIL SUALMAN \\ Universiti Teknologi MARA
}

\begin{abstract}
Stringent border control is one of the methods to secure national security across the world. Securing the border is essential for both economic and political reasons. In Sarawak, border security is one of the most discussed topics on the social media domain when it comes to state security concerns. Due to the porous Sarawak-Kalimantan border, a worrisome number of illegal activities had been recorded. Throughout the years, cases such as illegal crossings, drug syndicates, kidnapping, auto theft, smuggling, infiltration of illegal immigrants were reported to local authorities. These are among many other cases that highlight the gravity of the security issue near the Sarawak-Kalimantan border. Despite the continuous effort to increase security by Sarawak government through establishments of five new guard posts in Sarawak in 2018, security issues near the borderline is still a great concern. Sarawak is vulnerable not only along its border with Indonesia but also its shore and airspace. This research aims to explore the contemporary security issues near Sarawak-Kalimantan borders and efforts taken by the authorities to minimize security threats along the borderline. Through content analysis of Facebook discourse on security issues in Sarawak and in-depth interviews with eight informants - the findings of this research are hoped to be able to provide more updated data on Sarawak security issues with particular focus on border safety.
\end{abstract}

Keywords: Sarawak, Kalimantan, security issues, border, national security.

\section{INTRODUCTION}

Sarawak, located in the Borneo part of Malaysia, is a state with various cultures and rich in biodiversity. The state which stretches along the coast of Borneo's northwest coast including many beaches on the South China Sea. Sarawak, unlike its peninsular counterpart, is considered behind in terms of infrastructural development - where many parts of its state are still rugged and dense with rainforests. Other than Sarawak, Borneo Island also housed another Malaysian state of Sabah, Brunei Darussalam, and also Kalimantan, Indonesia. This article will focus specifically on the border issues near Sarawak and Kalimantan (MalaysiaIndonesia) borders. According to Dunan and Adnan (2017), there are three main issues that are often the trigger factors to the political rift between Malaysia and Indonesia, which are social, culture-and-art related issues, and border issues.

Malaysia and Indonesia are two allied nations, and we share many similarities and likeliness like arts, religions, language, and traditional cuisines. This commonness sometimes leads to heated disputes, which became more evident with the penetration of the Internet. The Internet has facilitation such opinions to be shared with greater audiences causing more divisions between people of the two nations (Jalli, 2016). The conflict between Malaysia beyond the media confrontation can be traced back to 1960s when the former President Sukarno disagreed with the formation of Malaysia (Liow, 2004; Petsch \& Clark, 2014; Irwansyah, 2017). The Indonesian president who viewed Malaya as the 'younger brother' was proposing the formation of a new Nusantara country called 'Indonesia Raya' (greater Indonesia) which includes the remaining archipelago in the Malay worlds. However, the call 
for the formation of such a nation was declined by leaders from Malaya. This has led to tension between the two countries. The rift between the two countries was then intensified when the Indonesian guerrilla initiated the Konfrontasi 1963 near Malaysia-Indonesian borders, including in Sarawak (Sutter, 1966; Suwirta, 2010). Konfrontasi, which translated as a confrontation in English, was a low-density war at the boundaries of the two nations by Indonesia to provoke the sovereignty of the newly formed Malaysia. The attack lasted for three years from 1963 until 1966 (Chua, 2001).

The attack near Malaysian borders dominantly in East Malaysia was a part of the Ganyang Malaysia campaign in 1963 initiated by Sukarno. In Sarawak, on April 12, 1963, Indonesian guerilla began to sneak into Sarawak borders, and among the first attacks by the guerilla was recorded in Tebedu Police Station, about five kilometers from the Indonesian border. Major Moerdani led the attack. However, his team was successfully defeated by the Royal Malay Regiment and the Gurkha soldiers (Van Der Kreof, 1968). Indonesia, at the time, justified their attacks towards Malaysia as a counterattack to the 'security threat' posed by Malaysia towards Indonesia through its establishment (Chua, 2001). This critical event in the Malaysia-Indonesia relationship, especially when it comes to border conflict, gives a backdrop on the ongoing issue of this matter between the two nations. Often, the diplomatic friendship between Malaysia and Indonesia is destabilized due to disputes over border issues.

This article explores the contemporary security issues concerning Sarawak-Kalimantan borders through the analysis of Facebook discourse on this topic as well as through correspondence with selected individuals in Sarawak and Kalimantan. We also look at the current efforts placed by local authorities particularly the Sarawak government in mitigating security issues near Sarawak-Kalimantan borders. It is hoped that through this exploratory research, we will be able to provide contemporary data on the issue of national security and state borders in the context of Sarawak.

This article is organized in six different sections, where the first three sections will provide an overview of issues related to border safety and national security. In the first three sections, we argue that border safety is a reflection of national sovereignty, a view shared by many scholars such as Wolfer (1952) and Brown (1977). We also highlight some of the contemporary issues related to issues near the Sarawak-Kalimantan border through the overview of border-related issues in a broader Malaysian context. Similar border issues found in other Malaysian borders in Peninsular, which is currently faced by authorities near Sarawak borders. We also provide the historical context to Sarawak border control through our discussion on the defunct Border Scouts and Sarawak Rangers.

The following section highlights our research methods, which is a close analysis of Facebook discourse as well as personal correspondence with selected individuals in Sarawak and Kalimantan. In the section on research findings, we presented our results in two subsections; 1) results derived from the analysis of Facebook discourse, and 2) results from in-depth interviews with selected informants. Finally, we conclude with a summary of overall findings derived from the analysis in each section, a discussion of their implications, and suggestions for further research.

\section{BORDER SAFETY AS A REFLECTION TO NATIONAL SOVEREIGNTY}

Issues related to border safety is not a new issue in Malaysia as our country is surrounded by other nations such as Thailand, Indonesia, and Brunei. Border control is a symbol of national sovereignty, and any form of external aggression to infiltrate our borders should be taken seriously. However, scholars have argued that authorities often overlook the border issues 
(Caballero-Anthony, 1998; Rohin \& Ahmad, 2017). Issues related to border security will only be debated in the public sphere whenever significant incidents occurred, such as the kidnapping of Malaysians near Sabah's water or the discovery of massive graves in Wang Kelian in Perlis believed to be victims of a human trafficking ring (Mat, 2016).

According to Mat (2016), criminal syndicates, cross-border terrorist activities near Malaysian borders are not based on short term plans, but through cohesive planning by criminal organizations. He also posited that despite the existence of border controls, places like in the Northern Peninsular, cross-border illegal movements happen daily. The most critical part of the situation is the illegal border crossings have become a component of the local culture, making it challenging to handle. According to Kedah Security Agency (AKSEM), villagers near the state border also partake in illegal smuggling activities from Thailand, putting national security at stake. The same issue has been observed near SarawakKalimantan borders where the illegal activities, particularly the illegal crossings facilitated by locals who are already accustomed to the activities for decades (Van Der Kroef, 1968). Due to the proximity of communities near borders despite their different national identities, illegal crossings are seldom viewed as a serious criminal offense by the locals (Sanderson, 2016).

Despite criticism towards Malaysian authorities, it could be seen that the Malaysian government is increasing its effort to secure national borders as reflected in the National Defense Policy (NDP), which aims explicitly to defend Malaysia's strategic interests and to safeguard national security. Currently, the NDP outlines three main principles, namely the national strategic interests, defense principles, and defense concepts. It is hoped that through NDP, Malaysia will be able to maintain its national security through a stable and peaceful strategic approach. Some of the strategic areas outlined in the policy could be explored in three layers; national, regional, and global with a specific focus on the safety of the mainland, national waters and space, the Exclusive Economic Zone (ZEE), the Malacca and Singapore Straits, and the sea and air links between West and East Malaysia.

Sarawak authority, specifically in recent months, had made public statements to increase border security through the proposed project called the Sarawak Border Security Road program. According to Sarawak Deputy Chief Minister, the implementation of the project will be vital in protecting Sarawak's multi-billion-ringgit assets, particularly the SabahSarawak Gas Pipeline (SSGP) and the four hydro-electric power (HEP) dams, which are near to Sarawak's international border with Indonesia (Tawie, 2019).

ISSUES NEAR SARAWAK-BORDER

This section will highlight some of the issues near Sarawak-Kalimantan borders, 1) the dispute over the territorial boundary and 2) transnational illegal activities.

\section{Disputes Over Territorial Boundary}

According to Wain (2012), most border disputes can be traced back during the colonial era when European nations imposed the alien concept of fixed borders on Southeast Asia between the nineteenth and early twentieth centuries. The white colonizers rarely consulted the traditional kingdoms, sultanates, and chiefdoms. Colonizers such as the British and the Dutch assumed power over local matters into their own hands. They carved up the region among themselves by taking into consideration places with economic and diplomatic advantages. While the successor independent states largely accepted the borders, inconveniently and arbitrarily drawn though they were, the region inherited numerous 
boundary discrepancies, which has resulted in the contemporary disputes over territory in Southeast Asia (Chua, 2001).

Malaysia and Indonesia have a series of disputes over territorial boundaries. For example, the cases on Camar Bulan and Tanjung Batu disputes. Camar Bulan and Tanjung Datu dispute are considered the climax of the long border dispute history between Indonesia and Malaysia. As previously illustrated, the Malaysia-Indonesia borders near Tanjung Datu follows the boundaries set by the former colonizers, the British and Dutch, and later followed by the predecessors who ruled Sarawak and Kalimantan (Irwansyah, 2017). The dispute over these territories was caused by the allegations that Malaysia had illegally occupied 1,499 square kilometers at Camar Bulan in Tanjung Datu. Malaysia was also accused of moving the boundary marker in the area, causing Indonesia to lose $800 \mathrm{~m}$ of its beach. This, however, denied by the Malaysian government, citing that the polemic was made by certain politically motivated individuals to create a political schism between Malaysia and Indonesia. Other than Camar Bulan and Tanjung Datu, any border disputes between the two countries remained until today for areas such as Ambalat Block, Sipadan, and Ligitan Island (Anom, Kee, Zawawi, 2014).

\section{Transnational Illegal Activities}

In this section, we highlight two of the most common illegal activities happening near Malaysian borders.

\section{a. Trade of Stolen Cars}

There are still minimal studies that have been done to look at the trade of stolen cars in Malaysia, particularly ones involving transnational movement through Sarawak-Kalimantan borders. In Malaysia, the business of stolen vehicles is considered a lucrative billion-ringgit industry. In 2013 alone, over 70847 cars worth RM 1.6 billion were reported taken nationwide (Zolkepli, 2019). Although in the past five years, the police managed to break a few major car theft syndicates, the number of stolen cars is still at a worrisome level, although there was a significant decline in the term of number was recorded. In 2018, 35953 cars were reported missing (Zolkepli, 2019).

The typical modus operandi for car theft criminal syndicates, according to Bruinsma \& Bernasco (2004), is through divisions of tasks. A division of the cartel would be assigned to steal an "on-demand" car while another group is responsible for "recycling," i.e., fitting it with a new identity by changing its physical characteristics and forging its papers' (p. 86). Car theft cases have been recorded in Sarawak for many years, with the majority of the cars stolen are SUVs and four-wheel drives such as Hilux and Tritons. In 2013, SUV owned by a Sarawak's Minister was recovered near the Sarawak-Kalimantan border near the Serikin border post. The syndicate was caught during the process of deporting the Toyota Fortuner to Indonesia (Yu Ji, 2013). In 2016, Royal Malaysia Police shared on Facebook how the police apprehended the Indonesian National Army (TNI) in Lubuk Antu, Sarawak believed to be driving a stolen vehicle that was reported missing in Samarahan. The four-wheel drive (4WD) was found after GPS installed by the owner showed that the vehicle reentered Sarawak from Kalimantan. The Indonesian soldiers said that they rented the car from a longhouse in Babang, Indonesia before entering Malaysia. 

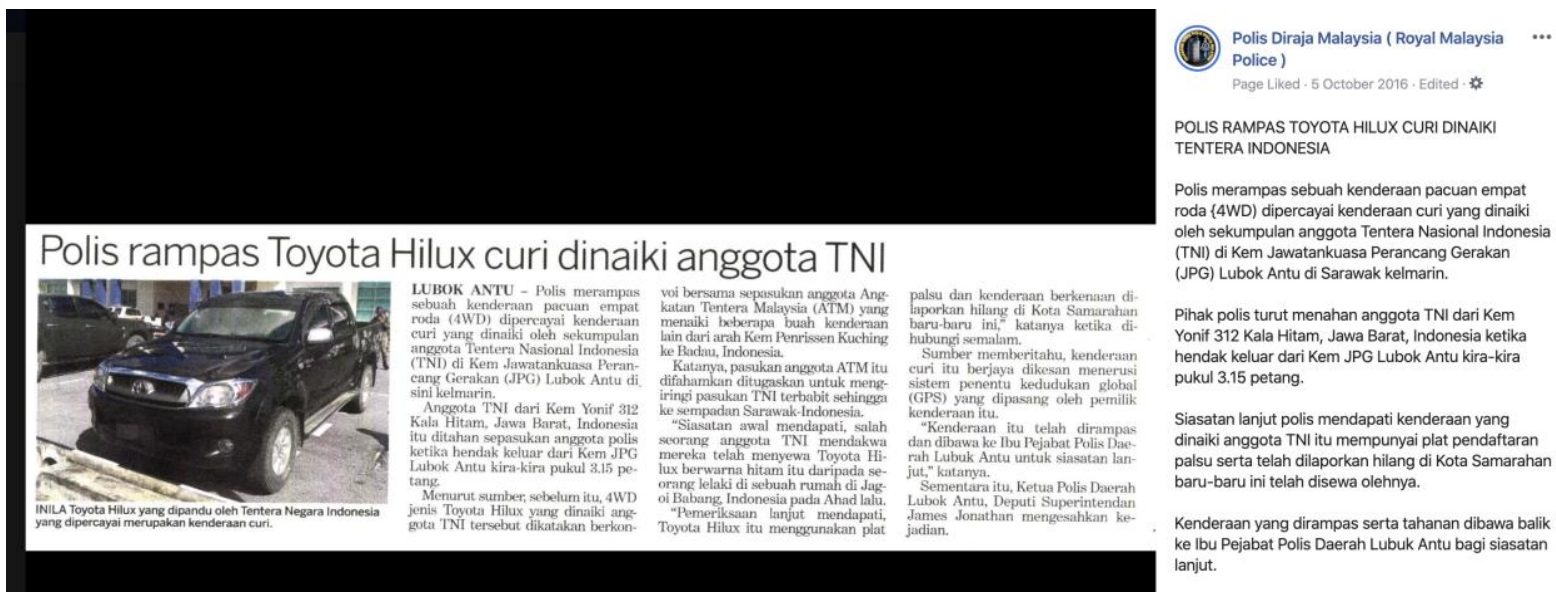

Figure 1: Facebook post shared by Royal Malaysia Police on October 5, 2016 related to the seizure of stolen Toyota Hilux driven by the Indonesian National Army in Lubuk Antu, Sarawak.

\section{b. Illegal Workers}

The migration of illegal workers to Malaysia through Malaysian borders has been an issue for decades (Dannecker, 2005). The Malaysian economy is booming, and the various development projects underway are creating employment opportunities, especially in the construction, manufacturing, and plantation sectors. The rapid development has created a shortage of workforce in multiple industries. This factor has made Malaysia an attractive destination for illegal immigrants, mainly from neighboring countries, including Indonesia (Liow, 2003). The entry of these illegal immigrants has created a sense of uneasiness and insecurity among Malaysian citizens, as criminal cases involving illegal immigrants have been recorded many times.

According to the Department of Information Malaysia (2015), there are several ways of how illegal immigrants entered Malaysia.

- Malaysian borders - where infiltration of illegal immigrants typically from neighboring countries via land or river.

- Through Malaysian waters - illegal immigrants enter Malaysia by boat and then stopping by the international water and not anchoring. Illegal immigrants later will swim to reach the beach or land.

- Through the 'main door' - where immigrants entered Malaysia with tourist visas and remain in the country beyond their visa limit.

- And lastly, through marriage with the locals.

Malaysia attracts illegal immigrants due to the following factors. The first influencing factor is the prosperity of the country, and the peace of life of the people of Malaysia is considered an attractive factor for foreigners, especially from Indonesia Bangladesh Myanmar India, Philippines Pakistan, to enter the country. Secondly, there are many job opportunities in the industrial trade services construction sector and as domestic helpers. Also, wages received by foreigners are considered high because the value of their country's currency is much lower than the value of the Malaysian ringgit (Department of Information Malaysia, 2015). Advances in infrastructure and construction are booming, and these foreign workers are willing to work longer hours to earn a decent income while locals are not interested in working in the sector. The similarity of social and cultural values with their home 
country is also a significant factor. And also, the long and wide shores of Malaysia and poor border control at certain border posts, facilitate their infiltration to the country without being detected by Malaysian authority (ibid.).

According to Liow (2003), if the flow of illegal immigrants into Malaysia is not controlled cohesively, the migration flow of Indonesians into Malaysia is arguably the second-largest flow of illegal immigrants after the movements across the U.S.-Mexico border. The issue of the migration of undocumented Indonesian labor to Malaysia has been a persistent source of discord in Malaysia-Indonesia ties for the years (Hugo, 1993; Kassim, 1997; Liow, 2017). There has been a series of protests by Indonesian politicians, media, and the public in response to stricter laws enacted by the Malaysian government against illegal workers. The move to strengthen laws against illegal Indonesian workers, subsequently affecting the vulnerable diplomatic relationship between these two countries (Liow, 2003)

\section{THE SARAWAK-KALIMANTAN BORDER: AN INTERESTING PARADOX}

While there are security issues near the border of Sarawak and Kalimantan, there are still good points that worth a revisit. For example, due to the porous borderline between these two states, economic activities flourish near the border, allowing transnational transactional activities between people of Sarawak and Kalimantan. People living near Sarawak and Kalimantan borders have lived in peace through cultural sharing and active economic activities (Bariyah, Lau, \& Mansor, 2012; Awang, Sulehan, Bakar, Abdullah, \& Liu, 2013). Due to the proximity of both states, people on both sides of the borders have had blood, and social ties since long before modern geopolitical boundaries were established (Ardhana, Langub, \& Chew, 2004). The relationships between the people within the border proximity despite their different nationalities, continue to thrive through trading activities in places like Pasar Serikin Sarawak (Abu Bakar, Abdullah, Awang, Sulehan, \& Liu, 2012).

However, despite the positive side effects of our porous borders, increased concern over security issues raised by many parties should be addressed. Locals have been pushing for the Sarawak government to take appropriate action, such as the potential of restoration of the now-defunct Border Scouts and Sarawak Rangers. Local leaders have also made the same statement, such as vice-president of Parti Rakyat Sarawak (PRS), Datuk Liwan Lagang, and the President of State Reform Party (STAR), Lina Soo. They urged the federal government to revive the Border Scouts and Sarawak Rangers to enhance the security along the border ("Star president supports call to revive Border Scouts, Sarawak Rangers," 2019).

\section{SIGNIFICANCE OF THIS RESEARCH}

Through this research, we aim to look at the contemporary security issues near SarawakKalimantan border. We also explored the current narrative on Facebook related to SarawakKalimantan borders. With limited scholarly writing on issues related to security issues near Sarawak borders - this research will open doors for further discussion on this issue. Data gained from this study can be used by scholars and governments alike to further explore potential solutions to mitigate existing security problems near the national border.

\section{METHODOLOGY}

There were two research methods employed for this study, which were a content analysis of Facebook discourse related to Sarawak-Kalimantan borders and in-depth interviews. The triangulation of several research methods in research is deemed necessary to achieve rigor and increased findings reliability. 


\section{a. Content analysis on Facebook discourse}

Content analysis is a method used to analyze written, verbal, or visual communication messages (Elo and Kyngäs, 2008). Content analysis is also a technique that systematically interprets and objectively identifies the unique characteristics of the message (Muluf, 2014). Content analysis was employed in this study to examine the extracted Facebook posts and comments. For this study, Facebook posts and comments were collected from September 1, 2018, until September 30, 2019.

\section{b. In-depth interview}

The data was gathered using an in-depth interview to ensure that we gained comprehensive data and information. According to Tracy (2019), an in-depth interview is useful when researchers want detailed information from informants on specific issues. A semi-structured interview guideline was constructed to assist with the interview process. A semi-structured interview will provide the participants with the freedom to express their opinions, and at the same time, the researcher had the flexibility to probe questions to obtain more information (Tracy, 2019; Saldana, 2013).

In-depth interviews in this research served as a complementary method to gain a holistic view of security issues near the Sarawak-Kalimantan border and the current narrative on the problems, particularly on social media. For in-depth interviews, the participants for this research were selected based on a purposive sampling, where they were identified based on their familiarity with the Sarawak-Kalimantan border issues. There were eight (8) chosen informants; five (5) were interviewed in Sarawak, Malaysia, while the other three (3) were interviewed in Pontianak, Kalimantan. Each interview session was recorded and was transcribed into text for analyzing purposes. All interviews were conducted face-to-face with an approximate duration of one hour per informant. In this paper, out of the eight (8) informants interviewed, three (3) will not be identified with personal identifiers' identifiers to protect informants' identities as requested by the informants. Data collection was from March 1, 2019, until April 30, 2019, in Sarawak, Malaysia, and Kalimantan, Indonesia.

Table 1: List of informants

\begin{tabular}{|c|c|c|}
\hline No & Name/Identifier & Note \\
\hline 1 & $\begin{array}{l}\text { Gerald Rentap Jabu } \\
\text { Member of Sarawak State Legislative Assembly }\end{array}$ & $\begin{array}{l}\text { Interviewed in Kuching, Sarawak, } \\
\text { Malaysia }\end{array}$ \\
\hline 2 & $\begin{array}{l}\text { Dr. Syarafuddin } \\
\text { Historian, Fakultas Ilmu Sosial dan Universitas Tanjungpura, } \\
\text { Pontianak, Kalimantan }\end{array}$ & $\begin{array}{l}\text { Interviewed in Pontianak, } \\
\text { Kalimantan, Indonesia. }\end{array}$ \\
\hline 3 & $\begin{array}{l}\text { Dr. Herlan } \\
\text { Deputy Dean, Fakultas IImu Sosial dan Universitas } \\
\text { Tanjungpura, Pontianak, Kalimantan }\end{array}$ & $\begin{array}{l}\text { Interviewed in Pontianak, } \\
\text { Kalimantan, Indonesia. }\end{array}$ \\
\hline 4 & $\begin{array}{l}\text { Dato' Sri Dr. Haji Wan Junaidi Tuanku Jaafar } \\
\text { Member of Parliament P139 Santubong }\end{array}$ & $\begin{array}{l}\text { Interviewed in Kuching, Sarawak, } \\
\text { Malaysia }\end{array}$ \\
\hline 5 & $\begin{array}{l}\text { Dato' Clarence Rorote Sagon } \\
\text { Deputy Director of Research } \\
\text { State Security and Enforcement Unit }\end{array}$ & $\begin{array}{l}\text { Interviewed in Kuching, Sarawak, } \\
\text { Malaysia }\end{array}$ \\
\hline
\end{tabular}


$6 \quad$ Informant \#6

Informant \#7

8

Informant \#8
Illegal Indonesian worker. Decided not to disclose personal identity. Interviewed in Miri.

Former illegal worker in Sarawak. Decided not to disclose personal identity. Interviewed in Pontianak, Kalimantan.

Member of a local political party. Decided not to disclose personal identity.

\section{Method of Analysis: Thematic Analysis}

Data obtained from Facebook and in-depth interviews later analyzed using thematic analysis. Thematic analysis is a technique to examine data in identifying the themes (or patterns) within qualitative data (Clarke \& Braun, 2013). Thematic analysis is a flexible method to identify themes or patterns of a language because of its applicability within a range of theoretical frameworks (Aronso, 1995). It is not tied to or require any specific theory of language or explanatory framework for it to work. Thematic analysis is a useful analysis method in a data-driven analysis that is meant to understand the representation of phenomena (Lindlof \& Taylor, 2017). Thematic analysis for this study was done in two stages, the first stage focusing on the content retrieved from Facebook and followed by the second stage, analysis of transcribed transcripts from the in-depth interview sessions.
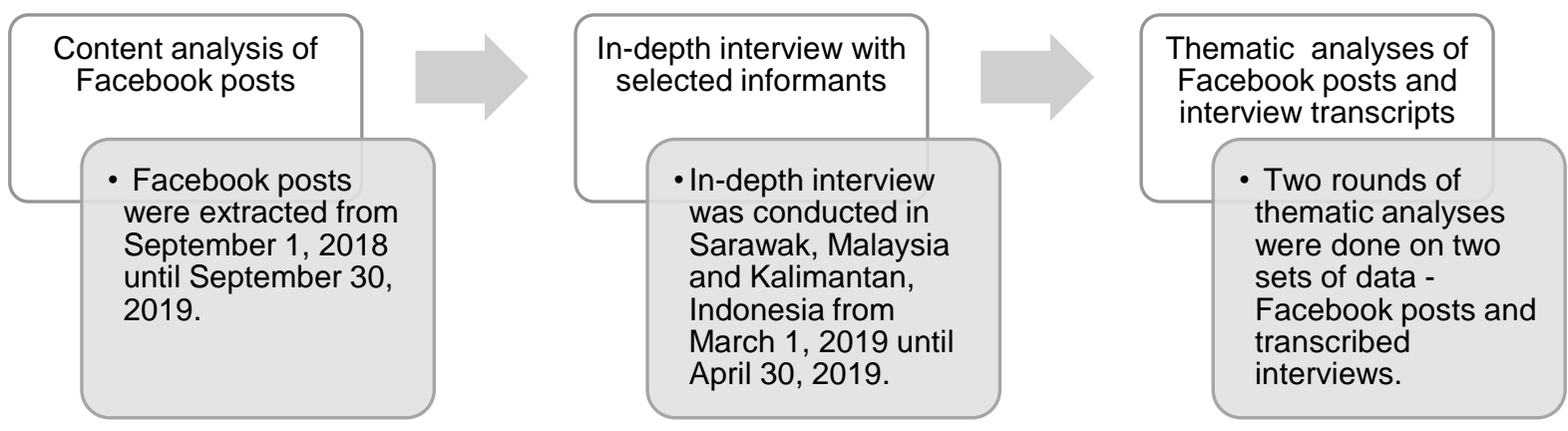

Figure 2: Data collection and analytic process

\section{FINDINGS}

\section{Thematic Analysis on Facebook Discourse}

Thematic analyses were done on both sets of data from Facebook discourse and in-depth interviews. Results can be referred to in Table 2 and Table 3. 235 Facebook posts were extracted from the social media site to study the current narrative on border issues near Sarawak and Kalimantan. However, after data cleaning, only 211 posts were selected for analysis. Posts analyzed in this study included status updates and users' comments. Results of a content analysis revealed that there are three dominant themes emerged related to Sarawak-Kalimantan borders. The emerged themes can be found in Table 2. 
Table 2: Emerged themes from extracted Facebook posts

\begin{tabular}{ll}
\hline Theme 1 & Cross border illegal activities due to poor border control \\
Theme 2 & Stricter border control near Sarawak-Kalimantan state line \\
\hline
\end{tabular}

\section{Cross-Border Criminal Activities Due to Poor Border Control}

The most prevalent theme from the analysis on extracted Facebook posts is the poor border control contributes to the existing problems on illegal cross-border activities. Some of the illegal activities highlighted by Internet users are including illegal crossings, cross-border automobile theft, the trafficking of illegal immigrants into Sarawak, as well as drug-related crimes. The recent announcement on the relocation of Indonesia's capital to East Kalimantan also raised concerns among some of the Internet users as it could catalyze the increased number of security threats near the border. The expected 30 million Indonesians to relocate to the new capital would attract a potential influx of immigrants to Sarawak. For example, one of the comments left on NCR Sarawak Facebook group stated,

"Anang ila mayuh sidak ia ba ditu ti Jokowi pindah ba Kalimantan!" (Later, do not be too surprised if many of them [referring to the illegal immigrants from Indonesia] are here.)

Another supported his comment, "betul tu, kena jaga-jaga barang rumah habis kena curi nanti bawak lari Indon" (You're right, have to take care of our house appliances or else will be taken and brought back to Indonesia).

This also illustrates the long-embedded stereotypes against Indonesian immigrants in Sarawak's public sphere. Some of the users also highlighted on the maritime issues with Indonesian fishermen. For example, one Internet user wrote,

"Kalau ngail kadang kadang ada tengok macam orang Indon dekat laut sana. Tidak ada polis pun tangkap? Polis tido ka??" (Sometimes when fishing at the sea, I see Indonesians [on our seawater]. No police detain them. Are the policemen sleeping?).

The inclination to blame local authorities could be seen through the comments left on content related to Sarawak-Kalimantan borders. Other transnational illegal activities highlighted by Internet users also include transnational drug syndicate, illegal crossings, the kidnapping of local people, and auto thefts.

Steven Sallez Steven Sallez Ada kes di sarawak orang indon jual p .jual tahi dadah..x de passport..membunuh orang tempatan..dan paling saya benci berani jual tahi dadah kpd orang tempatan walau d serbu berkali oleh polis..jual tahi dadah di negeri orang..x malu..bagus dia punya kepala potong saja..biar balik kmpung badan saja..

Like · Reply · $44 w$

Figure 3: Example of one of the comments in Malay left by a Facebook user, Steven Sallez Steven Sallez. Censored word is referring to female genitalia in the local dialect. 
We found that the current narrative on Facebook at least tends to incline towards highlighting the illegal activities due to the loose border control by the authorities. Although the blame tends to be pushed towards Indonesia nationals, some also said local criminal syndicates are also benefitting from the vulnerable Sarawak's border. Results also revealed that most of the conversation related to Sarawak highlighted weak border control allow for villagers living near the border to easily cross by merely writing their names and identification number in a logbook by the border post. Say, for example, an Internet user by the name of Raydee Asfieya said (the original comment was made in Sarawak Malay, refer to Figure X), 'In 2015 when the road has yet to be constructed, we only used the boat to Telok Melano. At that time, we could also use a motorbike from Kampung Telok Melano, write your name and your identification card number in the border post's logbook."

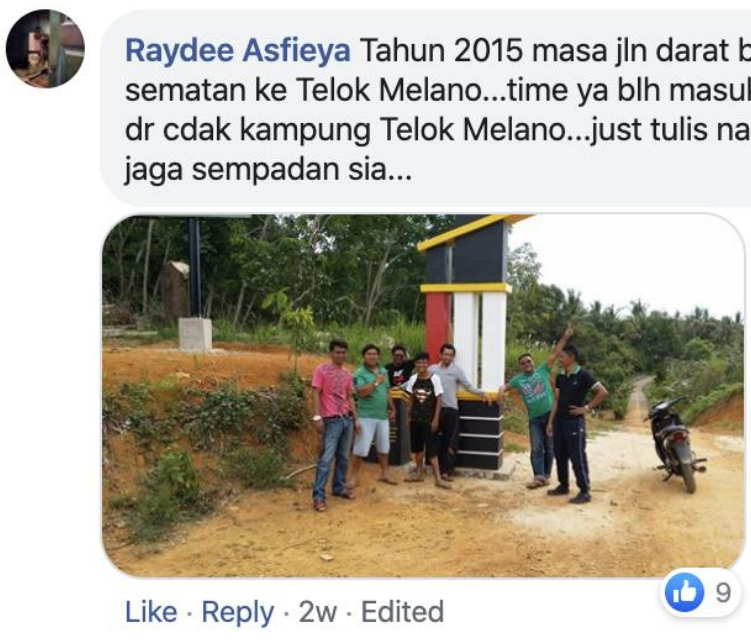

Figure 4: Original screenshot from Facebook public post.

Some online users also highlighted that they saw the encroachment of Indonesian soldiers into Sarawak soil, especially near the palm oil plantations area. And in 2018 , the police also apprehended two National Indonesian Army (TNI) soldiers at Ladang Roso in Lundu, Sarawak. They both were found driving on a stolen bike, with one of the soldiers were equipped with a rifle with 15 live bullets. It was also found that the motorcycle was reportedly taken in Kuching in 2017 (Kawi, 2018). Interestingly some also raised concerns over the plan by the state government to develop borders along Sarawak-Kalimantan Stateline. For example, a Facebook user by the name Ripu Jempur wrote, "recently I read Masing (referring to Tan Sri Datuk Amar Dr. James Jemut Masing) pushing for the construction of new border from Kuching to Sabah. It is a good and a bad thing. I am afraid it will open up more jalan tikus [illegal road] since the whole border got road link."

\section{Stricter Border Control Near Sarawak-Kalimantan State Line}

The second dominant theme found in the push for stricter border control by the state government. One hundred thirty-seven of the comments analyzed during content analysis highlighted poor border control by local authorities derived on a few assumptions such as poor infrastructural design, loose enforcement of laws, and potential corruption among border patrols. For example, one Internet user by the name of Pungai Cho insinuate Sarawak police incompetency in his comment 'Hoping that the police from Peninsular [Malaysia] can serve at the border with stricter enforcement on laws. If you rely on Sarawak police.. I don't know..no comment' (Original comment left was in Malay). 


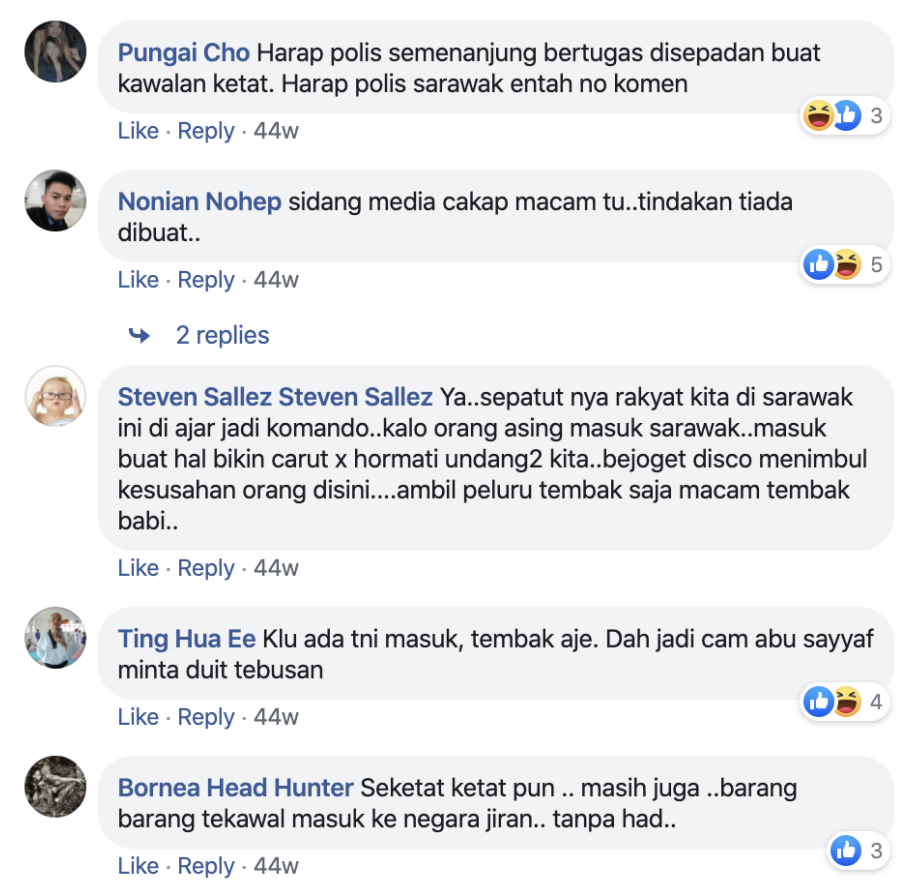

Figure 5: Original screenshot from Facebook comments related to Sarawak-Kalimantan border issues.

Another point that we found from our analysis is the push for reestablishment of the now-defunct Sarawak Rangers and Border Scouts in Sarawak to facilitate authorities in strengthening state borders. For example, one Internet user stated that reviving Sarawak Rangers and Border Scouts should be the top priority of the government as an effort to enhance border control mainly due to the upcoming relocation of Indonesian capital to East Kalimantan (see Figure 2).
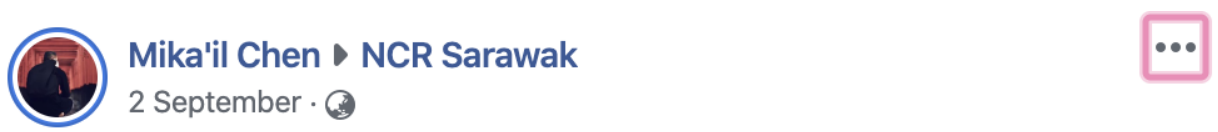

Reviving the Sarawak Rangers and Border Scouts is of utmost importance in view of the relocation of Indonesia's capital to Kalimantan. Better still if all Sarawakians undergo mandatory basic military training (BMT) similar to those of Taiwan and Singapore.

Figure 6: Screenshot of a Facebook post on the reestablishment of Sarawak Rangers and Border Scouts to assist with border control.

Based on the thematic analysis we could see there are a few security issues discussed in Sarawak online domain (see Table 3).

Table 3: Security issues most discussed by online users on Sarawak-Kalimantan borders

1. Illegal crossings.

2. Drug syndicates.

3. Kidnapping.

4. Auto theft.

5. Poor border control by authorities. 
Thematic Analysis of In-Depth Interviews

Through our conversation with the informants, we found three dominant themes as illustrated in Table 4.

Table 4: Emerged themes from an in-depth interview

\begin{tabular}{ll}
\hline Theme $\mathbf{1}$ & Increased efforts to strengthen Sarawak's border security \\
Theme $\mathbf{2}$ & Porous borders facilitate cross-border illegal activities \\
Theme 3 & Prosper thy neighbor approach \\
\hline
\end{tabular}

Theme 1: Increased efforts to strengthen Sarawak's border security

Based on our conversation with informants including local politicians, some said that over the years the Sarawak government has increased the effort to improve border security. For example, Dato' Sri Dr. Haji Wan Junaidi Tuanku Jaafar said,

"The state government already has a plan to better improve the existing security mechanism near Kalimantan. It is a continuous effort on our end not only to stop security problems but also to stop the flow of leftist ideology from entering the state."

After the interview with informants in April 2019, five months later, in October 2019, Deputy Chief Minister Tan Sri James Masing announced that the Sarawak government is initiating a new development plan to boost security near Sarawak borders. The project called the Sarawak Security Road Program that will cost RM 24 billion (Tawie, 2019).

Dato' Clarence Rorote Sagon of Sarawak State Security and Enforcement Unit posited that despite the increased control over the border, other perspective to mitigate illegal activities is through close monitoring of foreign activities in Sarawak land.

"Although we could see that the state government has increased its control over borders the past years. New border posts in certain places, there is still a great need to comprehensively improve cross-border immigration activities. It is important for our homeland and public safety" (Dato' Clarence Rorote Sagon).

Theme 2: Porous borders facilitate cross-border illegal activities

The second dominant theme found was how porous Sarawak borders facilitate cross-border illegal activities. 7 of the total informants interviewed highlight on this theme.

For example, based on our conversation with two Indonesian illegal workers, one said,

"Tidak susah masuk, pakai hilux tapok saja dalam kereta. Pakai jalan ladang. Sudah lama bisa bolos kalau tahu jalan. Kami sini pakai tokan bayar dia bawak masuk. Mereka tahu jalan". [It was not hard to enter Sarawak; we entered using hilux and hide in the car. We used plantation road. This is old tactic you can enter (Sarawak) if you know the way. We used a tokan (syndicate) paid him to bring us in. They know the way" (Informant \#6). 
We also spoke to professors from Universitas Tanjungpura on this issue. Both also highlighted that the Sarawak-Kalimantan borderline has a lot of loopholes allowing people from Malaysia and Indonesia to cross easily without proper documentation.

"Perbatasan Malaysia dan Indonesia di Kalimantan mudah ditembus terutama oleh mereka yang tinggal di dekat perbatasan. Mereka memiliki saudara di Sarawak terutama orang Dayak. Mereka tidak perlu dokumentasi yang lengkap, cukup tulis nama dan bisa pergi. Ini juga membuka pintu bagi sindikat kejahatan transnasional." [Malaysian-Indonesian border in Kalimantan is easily penetrated, especially by those living near the border. They have relatives in Sarawak, especially the Dayaks. You do not need complete documentation, just write your name, and you can go. This also opens doors for a transnational crime syndicate] (Dr. Syaraffudin, Universitas Tanjung Pura).

The same point was made by a Sarawak politician who wished not to be named. The similarity between the people regardless of their different nationalities making illegal crossing hard to detect.

"It's even harder for us to distinguish the local Iban Dayaks. Indonesian and Malaysian Ibans speak the same language, and many have cross-border relatives on the other side. The only way to single out Indonesian Ibans is by asking them to spell the alphabet $A, B, C, D, E \ldots$ you know. The way it is spelled is different from us since we use the British pronunciation" (Informant \#8).

The informant also raised concern over the complicated process of evicting long-term illegal immigrants in Sarawak.

"It is easy to let illegal immigrants and workers enter Sarawak; however, it would be complex to evict and deport them once they already settled and create troubles here. Look at our plantations area, we have so many illegal Indonesian workers there, and I would say there is a lack of 'spot checks' done by the police and authorities." (Informant \#8).

\section{Theme 3: Prosper thy neighbor approach}

According to Member of Sarawak State Legislative Assembly, Gerald Rentap Jabu while there are efforts placed by the government to improve border security, the government also implementing the friendlier approach in mitigating issues near the Sarawak state line. He said that the Sarawak government through Sarawak Energy employed the 'prosper thy neighbor' policy by establishing a good diplomatic relationship through the sharing of energy resources via the Sarawak-West Kalimantan Interconnection Project. According to Gerald, since Sarawak needs a monetary budget to implement comprehensive border control, 'prosper thy neighbor' deems relevant as an alternative approach. 
"We do not have the monetary budget to construct a wall like Donald Trump, we have to get creative with whatever we have. We, the Sarawak government believe in the prosper thy neighbor policy. We help the Indonesian government, and they will assist us with issues that could jeopardize our national security. If we can make friends, why make us enemies?" (Gerald Rentap Jabu, Member of Sarawak State Legislative Assembly).

The Sarawak-West Kalimantan Interconnection Project is a cross-border HVAC link connecting two systems at the Mambong 275kV substation in Sarawak to the Bengkayang $275 \mathrm{kV}$ substation in West Kalimantan, through a double circuit $275 \mathrm{kV}$ synchromesh line at a system frequency of $50 \mathrm{~Hz}$. Through the project, it is hoped to increase the security of supply through the sharing of spinning reserve, optimize operation cost through the sharing of spinning reserve and generation capability. This energy export program also aims to 'improve the reliability of the network, system frequency, and voltage control, provide support to cope with unexpected generation setbacks and unforeseen load growth, expedite economic collaboration between Sarawak and West Kalimantan and ultimately serve as an instigator for prospective potential interconnection (ASEAN Power Grid)' (Sarawak Energy, 2019).

\section{DISCUSSION}

Through our investigation on this topic, we managed to analyze some of the security issues deemed important in the social media domain related to the Sarawak-Kalimantan border. Based on our findings, we argued that there is an increasing concern over border safety among Sarawakians, particularly after the announcement by Indonesian President Jokowi on the relocation of Indonesia's capital city to East Kalimantan. It is also found that the existing problems near Sarawak-Kalimantan borders are believed to be caused by poor border control by local authorities and poor border infrastructure, especially at places prone to illegal crossings. Results also revealed that while the public domain tends to blame Indonesians for transnational unlawful activities, some users suggested the locals own some criminal syndicates. Indonesia is the 'black market' for illegal products such as drugs and stolen cars.

Results also revealed several contemporary issues are of the main concern among the people of Sarawak based on the responses towards postings related to Sarawak-Kalimantan borders on Facebook. Issues such as illegal crossings, drug syndicates, kidnapping, auto theft, poor border control by authorities. Through analysis of online comments and postings, it was evident that the public had low trust against the quality of border control by the Sarawak government at this moment.

However, it is also found that the Sarawak state has increased its effort to boost security near Sarawak state line through the establishment of new security posts near the borderline (Ogilvy, 2017). The initiative could also be seen through the recent announcement by Sarawak Deputy Chief Minister Tan Sri James Masing on the Sarawak Border-Security Road Programme in October 2019 (Tawie, 2019). It was also found that other than improving the structural component to securing the state border, the Sarawak government also adopted a strategic diplomatic approach through the Sarawak-West Kalimantan Interconnection Project by Sarawak Energy.

Due to limited research on this topic, it is hoped interested scholars could further explore the issues near Sarawak-Kalimantan borders. The data from the study not only beneficial for the state government as a reference to improve the existing condition but also provided the general public the extensiveness of issues created by weak border control. 
Eventually, a country's sovereignty and security are affected by how well the national borders are protected (Lane \& Kinser, 2001).

\section{BIODATA}

Nuurrianti Jalli, PhD is a research fellow (media warfare) at the Centre for Media and Information Warfare Studies, Faculty of Communication and Media Studies, Universiti Teknologi MARA. Email: nuurrianti@uitm.edu.my

Ismail Sualman, PhD is a Professor and Director at the Centre for Media and Information Warfare Studies, Faculty of Communication and Media Studies, Universiti Teknologi MARA. Email: ismail952@uitm.edu.my 


\section{REFERENCES}

Anom, E., Kee, M. D. C. P., \& Zawawi, J. W. M. (2014). Political discourse in Indonesia and Malaysia for national human security: A case study of lahad datu. Jurnal Komunikasi: Malaysian Journal of Communication, 30(2).

Ardhana, I. K., Langub, J., \& Chew, D. (2004). Borders of kinship and ethnicity: Cross-border relations between the Kelalan Valley, Sarawak, and the Bawan Valley, East Kalimantan. Borneo Research Bulletin, 35, 144-180.

Aronson, J. (1995). A pragmatic view of thematic analysis. The qualitative report, 2(1), 1-3.

Awang, A. H., Sulehan, J., Bakar, N. R. A., Abdullah, M. Y., \& Liu, O. P. (2013). Informal crossborder trade Sarawak (Malaysia)-Kalimantan (Indonesia): A catalyst for border community's development. Asian Social Science, 9(4), 167.

Bakar, N. R. A., Abdullah, M. Y., Awang, A. H., Sulehan, J., \& Liu, O. P. (2017). Kesejahteraan bersama melalui hubungan dagangan dan sosial di sempadan Kalimantan Barat dan Serikin, Sarawak (Shared prosperity through trade and social relations: The case of West Kalimantan-Serikin, Sarawak border area). Geografia-Malaysian Journal of Society and Space, 8(8).

Bariyah, N., Lau, E., \& Mansor, S. A. (2012). Long run sustainability of Sarawak - West Kalimantan cross-border trade flows. The Journal of Developing Areas, 165-181.

Brown, L. R. (1977). Redefining national security (No. 04; FOLLETO, 582.). Washington: Worldwatch Institute.

Bruinsma, G., \& Bernasco, W. (2004). Criminal groups and transnational illegal markets. Crime, Law and Social Change, 41(1), 79-94.

Caballero-Anthony, M. (1998). Mechanisms of dispute settlement: The ASEAN experience. Contemporary Southeast Asia, 38-66.

Chua, L. (2001). Konfrontasi: Rethinking explanations for the Indonesia-Malaysia confrontation, 1963-1966 (Doctoral dissertation, Massachusetts Institute of Technology).

Department of Information Malaysia. (2015, December 1). Pendatang tanpa izin. Retrieved from http://www.penerangan.gov.my/dmdocuments/pati/mobile/index.html\#p=4

Dunan, A., \& Adnan, H. M. (2017). Bingkai Malaysia dalam pemberitaan televisyen di Indonesia. Malaysian Journal of Media Studies, 14(2), 1-12.

Irwansyah, I. (2017). Border issue: Misperception between Indonesia and Malaysia. SHS Web of Conferences, 33, 00058.

Jalli, N. B. (2016). The effectiveness of social media in assisting opinion leaders to disseminate political ideologies in developing countries: The case of Malaysia. Jurnal Komunikasi: Malaysian Journal of Communication, 32(1).

Kassim, A. (1997). Illegal alien labour in Malaysia: Its influx, utilization, and ramifications. Indonesia and the Malay World, 25(71), 50-81.

Kawi, M. R. (2018, March 23). Anggota TNI ditahan ceroboh sempadan. Retrieved from https://www.bharian.com.my/berita/kes/2018/03/402819/anggota-tni-ditahanceroboh-sempadan

Lane, J. E., \& Kinser, K. (2011). The cross-border education policy context: Educational hubs, trade liberalization, and national sovereignty. New Directions for Higher Education, 155, 79-85.

Lindlof, T. R., \& Taylor, B. C. (2017). Qualitative communication research methods. Thousand Oaks: Sage publications. 
Ling, H. H. (2017). Penglibatan orang Cina dalam gerakan komunis di Sarawak, 19241974. SEJARAH: Journal of the Department of History, 23(1).

Liow, J. (2003). Malaysia's illegal Indonesian migrant labour problem: In search of solutions. Contemporary Southeast Asia: A Journal of International and Strategic Affairs, 25(1), 44-64.

Liow, J. C. (2004). The politics of Indonesia-Malaysia relations: One kin, two nations. UK: Routledge.

Liow, J. C. (2017). Malaysia's approach to Indonesian migrant labor: Securitization, politics, or catharsis?. In Non-Traditional Security in Asia (pp. 52-77). UK: Routledge.

Mat, I. (2016, August 16). Usaha jaga sempadan tidak perlu kata-kata manis. Press Reader. Retrieved from https://www.pressreader.com/malaysia/berita-harianmalaysia/20160818/281694024185188

Ogilvy, G. (2017, July 15). Five new security posts along Sarawak borders. The Star. Retrieved at https://www.thestar.com.my/metro/community/2017/07/15/five-new-securityposts-authorities-to-implement-tougher-enforcement-against-smuggling-alongsarawak\#UwcVWfXEJ76SUO4v.99

Pietsch, J., \& Clark, M. (2014). Indonesia-Malaysia relations: Cultural heritage, politics and labour migration. UK: Routledge.

Ramli, R., Kee, C. P., \& Sannusi, S. N. (2015). Pembingkaian berita persempadanan camar bulan dan tanjung datu, kalimantan barat. Jurnal Komunikasi: Malaysian Journal of Communication, 31(2), 341-370.

Rohim, N. Z. A. A., \& Ahmad, Y. (2017). Factors contributing to women trafficking in Malaysia: Perspectives from policy maker, implementers \& non-governmental organization. Journal of Administrative Science Special Edition: Socio-Economic Issue, 14(3).

Sanderson, S. (2016). Malaysian oil palm and Indonesian labour migration: a perspective from Sarawak. The Oil Palm Complex: Smallholders, Agribusiness and the State in Indonesia and Malaysia, 378-408.

Sarawak Energy. (2019). Beyond Sarawak - The Sarawak-West Kalimantan interconnection. Retrieved from https://www.sarawakenergy.com/what-we-do/beyond-sarawak

Star president supports call to revive Border Scouts, Sarawak Rangers. (2019, August 31). The Borneo Post. Retrieved from https://www.theborneopost.com/2019/08/31/starpresident-supports-call-to-revive-border-scouts-sarawak-rangers/

Sutter, J. O. (1966). Two faces of konfrontasi:" Crush Malaysia" and the Gestapu. Asian Survey, 523-546.

Suwirta, A. (2010). Dua negara-bangsa melihat masa lalunya: Konfrontasi Indonesia-Malaysia (1963-1966) sebagaimana dikisahkan dalam buku-buku teks sejarahnya di sekolah. Sosiohumanika, 3(2).

Tawie, S. (2019, October 25). Sarawak deputy CM: Urgent need for security road network along Sarawak-Kalimantan border. Retrieved from https://www.malaymail.com/news/malaysia/2019/10/25/sarawak-deputy-cmurgent-need-for-security-road-network-along-sarawak-kalim/1803757

Tracy, S. J. (2019). Qualitative research methods: Collecting evidence, crafting analysis, communicating impact. NJ: John Wiley \& Sons.

Van Der Kroef, J. M. (1968). The Sarawak-Indonesian border insurgency. Modern Asian Studies, 2(3), 245-265. 
Wain, B. (2012). Latent danger: Boundary disputes and border issues in Southeast Asia. Southeast Asian Affairs, 1, 38-60.

Wolfers, A. (1952). "National security" as an ambiguous symbol. Political science quarterly, 67(4), 481-502.

Yu Ji. (2013, 21 December). Sarawak minister's stolen SUV recovered. The Star. Retrieved from https://www.thestar.com.my/news/nation/2013/12/21/crime-sarawak-stolenrecover/

Zolkepli, F. (2019, March 27). Cops: Vehicle thefts on a decline. The Star. Retrieved from https://www.thestar.com.my/news/nation/2019/03/27/cops-vehicle-thefts-on-adecline 